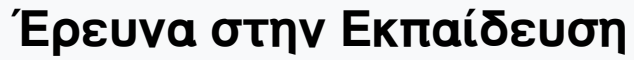

Tóp. 6, Ap. 2 (2017)

Special Issue: Lesson Study - A Scientific Meeting for Exchanging Views and Exploring the Model Across Europe

Special Issue dedicated to the Scientific Symposium with International Participation: Lesson Study: A Scientific Meeting for Exchanging Views and Exploring the Model Across Europe, Alexandroupolis, 7 and 8 March 2017
Ruptures and continuities between kindergarten and the first years of primary school

Anne Clerc-Georgy, Gabriel Kappeler

doi: $10.12681 /$ hire.14844

Copyright @ 2017, Anne Clerc-Georgy, Gabriel Kappeler

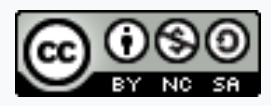

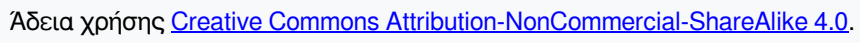

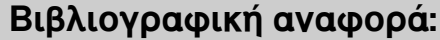

Clerc-Georgy, A., \& Kappeler, G. (2017). Ruptures and continuities between kindergarten and the first years of primary school. 'E 


\title{
Ruptures and continuities between kindergarten and the first years of primary school
}

\author{
Anne Clerc-Georgy, Professor \& Gabriel Kappeler, Associate Professor \\ University of Teacher Education, State of Vaud, Lausanne, Switzerland
}

\begin{abstract}
Summary
The aim of this article is to present the results of a lesson study which describes and analyzes the issues of transition between the kindergarten and the first grade of primary school. The lesson study was conducted with three groups of 10 teachers who teach the first four grades of elementary education, namely the kindergarten and first as well as the second year of primary school. Consequently, each team chose an item from the basic principles of subject-based teaching and learning applicable to the first four years of schooling. Each lesson was implemented in a kindergarten as well as in a primary classroom setting and observed by group members. Results from observations show individual rather than collective differences in teaching styles and practices of kindergarten and primary teachers in different levels. However, these differences are not clearly visible as they should be. Consequently, we'll argue that it is possible to bridge what these teachers believe as a "necessary rift" in their teacher styles and practices through mentoring.
\end{abstract}

C) 2017, Clerc-Georgy A., \& Kappeler, G.

Keywords: transition; kindergarten and primary school; lesson study; teacher practices

\section{Introduction}

In recent years, the framework and prescriptions for the early stages of schooling have changed in Switzerland, resulting in modifications to teaching practices implemented in these grades. The first years of schooling have become compulsory. The objectives of kindergarten are now included in the overall curriculum of compulsory schooling. As a result, new requirements for assessment and communication with parents have emerged. These new requirements, together with a profound change in the training of the teachers concerned (training carried out at university level, with a single diploma for all primary grades) have led young teachers to adopt new ways of working that are not always conducive to learning in the first grades of schooling. Indeed, the ways of working in kindergarten have gradually changed, imitating those typical of primary school ${ }^{1}$. Thus, young teachers tend to multiply the number of hand-outs (printed sheets taken from teaching aids or downloaded from the Internet) in the activities proposed to the pupils. This form of work frees the teacher of constraints related to managing the class and reassures him or her when it comes to keeping a record of pupil learning. Although the requirements state that assessment should be limited to pupil progressions and should take place only in learning situations ${ }^{2}$, teachers often give pupils individual assessment tasks, that tend to be 'written' and decontextualized. These findings are reinforced by the inventory of

\footnotetext{
${ }^{1}$ These findings have been told us by the inspectors or school directors who commission continuous training from us.

${ }^{2}$ These specifications come from the general evaluation framework for compulsory schooling in the canton of Vaud.
} 
Hellenic Journal of Research in Education, Special Issue dedicated to the Scientific Symposium with International Participation: Lesson Study: A Scientific Meeting for Exchanging Views and Exploring the Model Across Europe, Alexandroupolis, 7 and 8 March 2017

Gilliéron et al. (2014) denouncing a shift to a primary school approach in the first two grades of schooling. These practices entail the risk of evaluating only declarative knowledge to the detriment of fundamental learning ${ }^{3}$ (recitation of a rhyme about numbers rather than the construction of the notion of numbers).

With an increasing preference for this way of working, two other essential modalities at this age are gradually disappearing: play and the learning collective. On the one hand, teachers do not see play as a learning experience, but as a recreational pursuit relegated to the end of school 'work'. These teachers fail to identify the knowledge used by children during play. On the other hand, learning collectives are rarely conceived of as an opportunity for pupils to acquire rules for learning together and to grasp the meaning of subject-based tools proposed by school.

In our context, pupils attend the first two years of schooling (kindergarten) with one teacher and the next two with another (primary). This change produces a break between 5 and 6 years old, whereas learning at this age, in a Vygotskian perspective (Bodrova \& Leong, 2011), should be considered a continuity from 3 to 7 (advent of writing, construction of the concept of number, initiation into school ways of working and school subjects ...). In many schools, the management requires teachers of the first two grades to prepare reports for teachers of subsequent grades. This is the case in the institution concerned by the current training-research, where kindergarten teachers wrote individual reports for each pupil and passed them on to teachers of the first primary grade. This exchange did not go well, as primary teachers did not understand the contents and could not take advantage of them.

To ensure continuity between these levels, to promote the transition from child to pupil, from spontaneous learning to reactive learning (Clerc-Georgy, 2015, Vygotski, 1935/1995) and to facilitate the uptake of ways of working required by and for school (Cèbe, 2000), we suggested that teachers of all four degrees work together in a lesson study. Our assumptions being that this approach would promote:

- improved understanding of levels teachers did not teach at,

- enhanced skills in observing learning progressions,

- better mutual understanding of information exchanged by teachers about pupils.

\section{Fundamental learning}

By fundamental learning, we mean learning that is the foundation of successful schooling (ClercGeorgy, 2017). Our team is currently working on identifying and defining these types of learning. Thanks to our exploratory work and the state of play of our literature review, we can identify some dimensions of the knowledge to be taught and acquired by pupils in the first stages of schooling.

A first dimension concerns 'true' play (using Vygotski's terminology) or 'pretend' play. This type of play has three fundamental components: 1) children create an imaginary situation; 2) they endorse and play roles, and 3) they follow a certain number of rules determined by those roles (Vygotski, 1933/1967; Bodrova, 2008). This form of play is a Leading Activity, that is, the activity most likely to cause age-specific developmental gains, such as self-regulation, oral language, metalinguistic awareness or imagination (Bodrova, 2008, Bodrova and Leong, 2011, Charlesworth, 1998, and Clerc-Georgy, 2016). Pupils who have developed the capacity to engage in 'mature' play

\footnotetext{
${ }^{3}$ By fundamental learning, we mean that which is the foundation for successful schooling: the tools of thought (cognitive, affective and metacognitive) required by school, the development of a relationship to knowledge conducive to entering into school subjects (through the use of knowledge), the rules of learning together according to a rhythm, a program and imposed modalities.
} 
Hellenic Journal of Research in Education, Special Issue dedicated to the Scientific Symposium with International Participation: Lesson Study: A Scientific Meeting for Exchanging Views and Exploring the Model Across Europe, Alexandroupolis, 7 and 8 March 2017

are also those who show the most self-regulation in structured learning situations (Elias \& Berk, 2002).

A second dimension involves the uptake of proto-didactic knowledge, that is to say, what makes school work possible (Nonon, 2004), which addresses learning to learn (Chevallard, 1991). This includes enumerative, discriminatory or categorization skills.

A third dimension is linked to the process of making learning subject-based. Knowledge handled in these first stages is gradually and increasingly treated differently, according to the subject matter which is considered in different subject domains (for example, a fruit will be treated differently in a lesson on language, science, art or nutrition). In addition, some knowledge in a domain is often referred in an activity of another domain (enumeration to spell out the sounds of a word or literacy skills to organize a collection to be counted) (Laparra \& Margolinas, 2016).

A fourth dimension relates to developing the ability to change point of view on an object (Pramling Samuelsson \& Pramling, 2016), progressively adopting a school and subject-based perspective on the objects treated daily in school. Adopting a school perspective requires acquiring those skills required by school learning and often developed in play (voluntarily imagining learning as it is done in school, developing self-regulation capacities in school situations, becoming aware of the interest of the knowledge proposed). These school-related modes of thought are linked to the transition from spontaneous learning to reactive learning, as theorized by Vygotski (1935/1995), namely the ability to learn together according to a given rhythm, program and modalities.

A final dimension is linked to learning about participatory structures, a framework for raising questions (Amigues and Zerbato-Poudou, 2000), a collective effort requiring reaching an agreement and collectively adopting tools of thought under the guidance of a teacher. It involves constructing a conception of language not only as a tool for expression or communication, but also as a tool for reflection and learning. This dimension includes the development of the capacity to adopt and use different registers of thought and language (Bautier \& Rayou, 2013; Bautier \& Goigoux, 2004).

\section{The lesson study}

The lesson study is a form of research and training developed in Japan and widely practiced by the country's teaching staff (Stigler \& Hiebert, 1999). It is also used in many Asian countries. Called lesson study (LS) in the Anglo-Saxon world, this system proposes a training -research process involving teachers around a teaching-learning issue. The purpose is to improve the impact of the learning experiences teachers propose to their pupils. The central activity of this system is to have teachers work together on one or more lessons. Starting from a difficulty related to the material to be learnt, teachers study the notions to be acquired. They collectively plan a lesson. One of the teachers gives the lesson in his or her class while the others observe and gather information about pupils' learning processes. Finally, the group analyses the lesson given and measures its impact on pupils' learning. The group may decide to revise the lesson, or even re-plan a new lesson on the same topic.

Collaboration between teachers during the process is an important factor on the impact of the scheme for their professional development (Takahashi \& McDougal, 2016). The co-construction of lessons and the confrontation of points of view favour changes of perspective and enrich the phases of the process (Martin \& Clerc-Georgy, 2015). Moreover, this system has a significant impact on mastering the material to be taught (Fernandez, 2005) and the knowledge that is needed to teach. 
Hellenic Journal of Research in Education, Special Issue dedicated to the Scientific Symposium with International Participation: Lesson Study: A Scientific Meeting for Exchanging Views and Exploring the Model Across Europe, Alexandroupolis, 7 and 8 March 2017

\section{Methodology}

Three groups of 10 teachers from the first four grades of schooling (kindergarten, $1^{\text {st }}$ and $2^{\text {nd }}$ year primary) were formed. Each team chose an item of subject-based teaching and learning from the fundamentals appropriate to the first 4 years of schooling. For example, the first LS focused on writing and managing a complex task and the other on producing a written sentence and building autonomy in solving a task.

Each team studied the selected items and planned two lessons, one for Grades 1 and 2 (kindergarten classes) and one for grades 3 and 4 (first primary grades). Each lesson was implemented in a kindergarten class and in a primary class and observed by all group members. Subsequently, teachers analysed the lessons from the perspective of pupil learning. At the end of the two lessons, the exchange of thoughts was focused on the similarities and differences between these two levels and on the means to be developed to promote progression and continuity throughout the cycle.

In the training-research process, the co-construction and debriefing phases of the three LS were conducted in parallel. They were filmed to record the contents of exchanges and to facilitate the transcription of the discussions. During this first cycle of the LS, 9 hours of lesson preparation and 9 hours of post-lesson debriefing between teachers and researchers were recorded. These exchanges made it possible to highlight the proficiency and professional knowledge of the teachers in terms of their context and the level at which they teach, to co-construct shared representations of issues at stake in pupils' transition from kindergarten to primary school as well as to improve mutual understanding of other teaching levels. All these recordings were fully transcribed. At the same time, trainerresearchers also carefully transcribed observations gathered during the lessons.

For this first stage of exploration of the harvested material, data analysis is essentially content analysis. The categories of analysis are based on teachers' discourse about fundamental and subjectbased learning, on teachers' knowledge, skills and beliefs about pupils' transition from year 2 of kindergarten $(2 \mathrm{H})^{4}$ to year 1 of primary school $(3 \mathrm{H})$ as well as their observations on the progression of pupils' learning. Based on the categories chosen and the units of meaning that compose them, this exploration of the material harvested during these LS allows us to identify the continuities and discontinuities between the two years and to understand how they are created or even co-created within the same school.

\section{Results}

Analysis of the results suggests five thematic nuclei around which these results can be meaningfully organised. The problem of transition from kindergarten to primary school is evoked during discussions about teaching practices and styles, the treatment of subject-based items and fundamental learning, beliefs about the practices of teachers of other grades, perceptions of the skills of pupils of other grades, management of learning vs classroom management and conceptions about real play. Observations gathered by researchers in the lessons show that the stakes of the transition are not necessarily linked to the level at which the teacher teaches, but are related to many other factors including, amongst others, the beliefs and knowledge of teachers about the development and needs of 4-to-7-year-old pupils.

\footnotetext{
${ }^{4}$ The recently introduced Harmos system to harmonise compulsory schooling across Switzerland enumerates school years from the first year of Kindergarten $(1 \mathrm{H})$ to the last year of lower secondary school $(9 \mathrm{H})$.
} 
Hellenic Journal of Research in Education, Special Issue dedicated to the Scientific Symposium with International Participation: Lesson Study: A Scientific Meeting for Exchanging Views and Exploring the Model Across Europe, Alexandroupolis, 7 and 8 March 2017

\section{Practices and styles of teaching}

To begin with, it is important to note that teaching practices and styles vary from one teacher to another regardless of the level at which they teach. For example, we observed some teachers who invested more in classroom management, focusing their interventions mainly on the installation and maintenance of order, as well as the commitment and participation of pupils, whereas others were more concerned by the organisation of learning and the progression of pupils. In addition to the differences of individual teaching practices in the classroom, we observed that in the course of lesson preparations several teachers linked pupils' difficulties during the transition to differing styles of teaching in kindergarten and primary school.

“... For me, it is the gap between our two ways of teaching. It is still totally different and it remains a shock for the pupils who go from the 2 nd to the 3 rd year... But all things considered, we still have the same concerns..." (Emilie, 1-2H, G1)

Despite this observation, and like Sabrina, a kindergarten teacher, some primary teachers pointed to these differences saying that it is up to pupils to adapt. For example, Laurence, a primary teacher said that "... they [pupils] do not know us [3-4H teachers], they do not know our requirements. So, they need to adapt." (Laurence, 3-4H, G2). Or Lyne, also a primary teacher, thought that "... it is part of the pupil's job to learn to adapt, and finally to adapt to another teacher, to learn to adapt to another way of working, ..." (Lyne, 3-4H, G1). And finally, the following exchange between a kindergarten teacher, a primary teacher, a member of the management and one of the trainer-researchers also demonstrates that it is essentially for pupils to adapt to the practices and teaching style of a new teacher and not the teacher to adapt to the rhythm, knowledge and skills of his or her new pupils at the beginning of primary school.

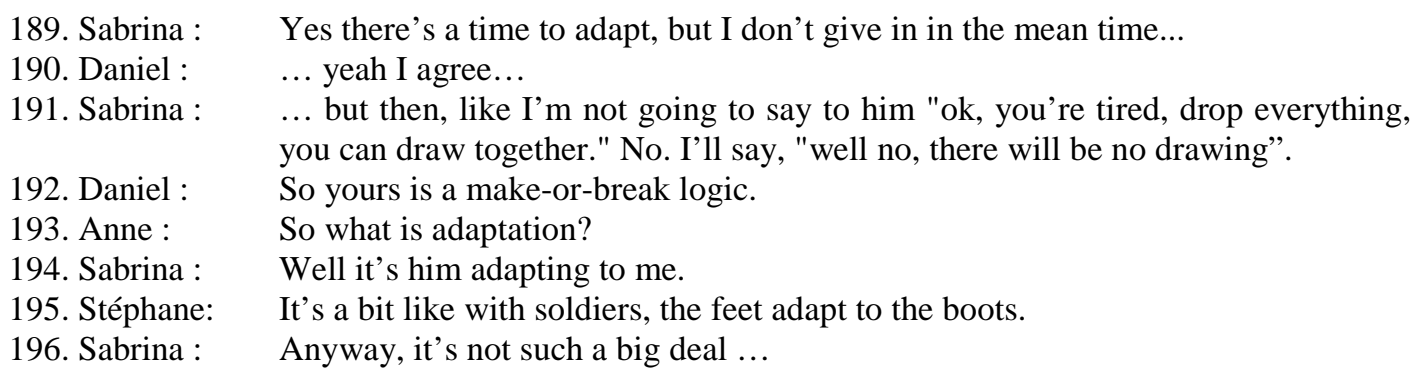

(Anne, Sabrina, Daniel et Stéphane, G1)

The problem of pupils adapting to new practices or teaching styles during their transition to primary school was widely debated in one of the LS groups. The kindergarten teachers argued in favour of the importance of maintaining and respecting instructions which, according to them, was one of the major preparations facilitating the transition and adaptation of pupils to primary school. Regardless of the teaching styles and practices, they considered that if the pupils could comply with instructions, the transition would take place more smoothly.

"That's why we leave no leeway when it comes to instructions. If we say, "we colour there, we colour in pink and blue'. You don't use red because it's our job to start teaching them how to follow instructions." (Emilie, 1-2H, G1)

\section{Beliefs and expectations of teachers with respect to colleagues from other levels}

Observations gathered by the trainer-researchers throughout the negotiation process implementing these LSs revealed many beliefs about what is done in the respective levels. One of the objectives of the training was precisely to improve teachers' knowledge of levels they do not teach. Collectively sharing lesson preparation and post-lesson debriefing helped reveal these beliefs. Restricting oneself to 
Hellenic Journal of Research in Education, Special Issue dedicated to the Scientific Symposium with International Participation: Lesson Study: A Scientific Meeting for Exchanging Views and Exploring the Model Across Europe, Alexandroupolis, 7 and 8 March 2017

one LS cycle might lead to erroneous beliefs, to freeze those beliefs without undertaking the necessary deconstruction and the work of understanding other levels. We will return to this in the conclusion.

Above, we gave the example of a belief of Emilie, a kindergarten teacher, about the respect for instructions which she saw as a fundamental competence for those beginning primary school. In comparison, Sabrina, a primary teacher, imagined that kindergarten teachers were continually repeating instructions.

“... I found it very interesting [observing a lesson in $1-2 \mathrm{H}] \ldots$, but I realize that ... I have done internships in kindergarten, but in fact I realize what it is really like to teach kindergarten school, your way of doing things is just totally (...) you have to repeat 20'000 times the same things..." (Sabrina, 3-4H, G1)

Teachers' beliefs about the practices of colleagues in other grades indirectly lead them to formulate real expectations (primary teachers) or even imagined (kindergarten teachers) expectations, although these tend to be peripheral to fundamental and subject-based learning. As an example, Catherine, a kindergarten teacher, points out that "they [pupils] have no work-sheets, no schoolbags, no work-sheets to put away ... no homework. So it's all quite a discovery. We cannot really prepare them because, after all, we are not going to give them homework just so they are used to it" (Catherine, 1-2H, G2). And her colleague Lyne, a primary teacher, retorts that she finds "it hard when you [Catherine] say that pupils in your class do not learn all you have mentioned ... when we [teachers 3-4H] tell them 'do your work-sheet' and we get it back all written in green ... a work-sheet is done in pencil with us ... Haven't you got pencils?" (Lyne, 3-4H, G1).

In addition, one of the primary teachers points out that, for the last few years, she and her colleagues from primary school can no longer distinguish where class pupils come from. Indeed, these internal reflections helped reduce differences between classes. Nevertheless, she notes that there might perhaps be "a request, to do more oral work with syllables, splitting words into syllables" (Sabrina, 3$4 \mathrm{H}, \mathrm{G1}$ ), but that is only a detail. However, in one of the other LS groups, Laurence, a primary teacher, notes that there are sometimes "...tensions. I [Laurence] did not feel that, but I've heard colleagues saying that pupils arriving in $3 r d$ grade are not able to write in script. Perhaps that would be good. Just look at this notebook!..."(Laurence, 3-4H, G2). While some teachers say they no longer perceive tension, others mention specific expectations about skills that kindergarten teachers could still teach pupils before their first primary year. The example of the use of pencils, or that of the notebook or others, demonstrate the extent to which primary school teachers' expectations are focused on basic and very precise skills, to the detriment of complex fundamental learning for the future success of their pupils.

Finally, the time granted for pupils to learn and adapt to this new level was also discussed during the preparation and debriefing of lessons. A kindergarten teacher evoked the subject, saying that one of their aims was to ready pupils to engage in school learning processes. Indeed, Emilie, a kindergarten teacher, stressed that, "with time, our [her] job, from the beginning to the end of kindergarten, is to bring them to a point where they are ready, in the third year, to accept imposed moments of maths..." (Emilie, 1-2H, G1). Responding to this intervention, a primary teacher replied that, from the beginning of the 3rd year, the rhythm changed by saying that pupils "...didn't have 107 years to do things..." (Lyne, 3-4H, G1). It would seem, therefore, that the pace of work accelerates considerably and that the free choice of activities ceases in the move from one school year to the next. Paradoxically, primary teachers generally agree that pupils' adaptation at the beginning of primary school is difficult and that it takes some time for them to adapt to this new pace of work and that only "in November, can we [teachers 3-4H] start such things [academic and subject-based tasks]" (Laurence, 3-4H, G2). 
Hellenic Journal of Research in Education, Special Issue dedicated to the Scientific Symposium with International Participation: Lesson Study: A Scientific Meeting for Exchanging Views and Exploring the Model Across Europe, Alexandroupolis, 7 and 8 March 2017

\section{Teachers' perceptions of the competences of their pupils}

Above, we noted teachers' expectations and beliefs about their colleagues. They mainly formulated demands about basic or very specific skills. The analysis of our data shows that when they talk about new pupils starting primary school in their class, they are surprised at their lack of autonomy. For example, Sabrina, a primary teacher, says, "It's interesting because, I imagined that they already knew how to do that on their own because at some point they had to be alone to do that" (Sabrina, 3-4H, G1). Other primary teachers agree, and insist that pupils need to be able to work independently as quickly as possible. In addition, one adds that, for her, it is a priority before the autumn holidays. Only afterwards can they engage in subject-based learning. For kindergarten teachers, the notion of autonomy does not coincide with that of primary teachers. For primary teachers, a pupil's ability to perform a learning task alone is a question of autonomy.

On the other hand, primary school teachers do not consider differences between the way they organize work and class and how teachers of the preceding grades do. They do not accompany pupils in understanding and assimilating the new 'rules of the game'. For example, the LS revealed that in a kindergarten classroom, school material (pencils, gums, glue, scissors etc.) is collective and stored in one place, whereas in primary school, each student has his or her own material.

Finally, during the classroom and post-lesson debriefings, discussions focussed on aspects related to the organization and management of the class, such as listening to instructions, using a pencil or knowing how to raise your hand to speak. These discussions rarely concerned knowledge or the progress of students in their learning.

\section{Handling items to be learnt}

The first LS cycle revealed differences in the conception of issues related to complex learning such as reading and writing or the construction of numbers. The case of writing is particularly interesting since it potentially involves several different, overlapping kinds of learning such as graphic design, the direction of writing, knowledge of letters and the writing of sounds, the grapheme-phoneme relation, vocabulary or spelling. As an example of differing conceptions when it comes to writing, teachers preparing a lesson for early-stage writing did not agree on the objectives and expectations they associated with the activity. Patricia, a kindergarten teacher, believed that writing words correctly was not as important as the child's attitude to writing: "If you do early-stage writing, you do not attach too much importance to how they write a word provided it is written, it can even be scribbled, at least for me..." $(1-2 \mathrm{H}, \mathrm{G} 2)$. She went on to explain that she first sought to enable a grasp of the sense of the activity, instilling the knowledge to be acquired only gradually. In comparison, Justine and Laurence, primary school teachers, saw early-stage writing as a time to work on vocabulary. Moreover, Justine did not understand how writing could be undertaken before mastering reading, whereas the kindergarten teachers considered it essential to work on reading and writing in parallel.

This difference of expectations was reflected in the observation of pupils in class. Second-year kindergarten pupils, confronted with an early-stage writing activity for the first time, demonstrated an ability to use the phoneme-grapheme relationship. This ability surprised primary teachers. Strangely, pupils in the first year of primary education seemed to have completely lost the capacity. When writing, they systematically asked to be dictated the spelling of the word.

Another situation, linked to learning addition, showed that the complexity of knowledge required often led kindergarten teachers to 'take advantage' of the situation to include other learning (from other subjects or fundamentals). For example, Catherine, a kindergarten teacher, explained: “... Sometimes it happens that he's got so far, then, 'You are stuck. What are you going to do?' 'Oh yeah. I could turn it around, see?' I figure I can introduce something about handling space. (...) we can 
convey not only maths but also how to organise things..." (Catherine, 1-2H, G2). Anne, primary teacher, notes, "So, in fact, you drop the main objective which is maths" (Anne, 3-4H, G2). Valérie, a kindergarten teacher, provides another example about organizing pictures in a given order. These examples illustrate the extent to which tasks given to pupils in kindergarten can only be carried out if teachers also allow them to carry out other learning than that which was aimed at. Such learning is required to carry out the task and often involves fundamental learning (anticipating, organizing task resolution, managing space, respecting the order of writing...).

Finally, during the preparation of this mathematical activity, teachers realized how much time was spent on what pupils were asked to do (cutting out the pieces), when these activities were not related to the targeted learning (addition). Sabrina, a kindergarten teacher, said, "The only thing that annoys me with this kind of worksheet is the time it takes to cut out..." (Sabrina, 1-2H, G2). This is another dimension of fundamental learning: the ability to identify what is important, what is to be retained, to be generalized in an activity.

\title{
Representations of the role of play
}

As noted above, time devoted to play is disappearing in first-grade classes. Early-grade primary school teachers point out that there is neither the space nor the material for play in their classes. Lyne says, "We do not have a corner with material, we do not have 'freely available toys' in the free-play sense" (Lyne, 3-4H, G1). Yet they note that their pupils often ask to play. Certain teachers, whatever their grade, miss the point, failing to distinguish between play and game ${ }^{5}$. When pupils ask to play, they reply that there are many games in mathematics. The confusion is between games played and playful pedagogy. Other teachers, such as Lyne, understood the difference:

\begin{abstract}
"No, but 'free', when there is no maths goal, no specific French goal, like, 'I'm doing this game to work on that exactly.' While free play, I see free play, it is very open and I am going to work on a lot of things and I know I will achieve a lot, but I do not have a set goal for each game, "You're going to play with dolls because I want you to learn how to do up buttons." You see what I mean?" (Lyne, 3-4H, G1).
\end{abstract}

Classroom observations showed that understanding what free play was, real play, was not linked to teaching levels. Real play in kindergarten classrooms included activities as varied as pretend play, construction games, educational games and computer games. Although some primary teachers were convinced of the importance and stakes of real play for their pupils, the difference between teachers at the different levels was that they did not feel empowered to leave room for it.

Finally, during the first lessons carried out in kindergarten, the trainer-researchers noted that teachers did not observe moments of play. The debriefing showed that they did not know what to look for and especially that they were not aware that pupils made use of certain subject-based knowledge or fundamental learning during play.

\section{Conclusion}

The rift between kindergarten and primary school seems to have always been a source of grievance, even though pupils now start school earlier, all teachers are trained together and many counter-strategies have been implemented. The current analysis leads us to hypothesise that rather than fighting this feeling of rupture, it would be better to improve the accompaniment of what we prefer to call a 'necessary rift'

\footnotetext{
${ }^{5}$ In French play and game are translated by the same word: jeu.
} 
Hellenic Journal of Research in Education, Special Issue dedicated to the Scientific Symposium with International Participation: Lesson Study: A Scientific Meeting for Exchanging Views and Exploring the Model Across Europe, Alexandroupolis, 7 and 8 March 2017

To begin with, during the transition from kindergarten to primary school, children experience their first change of teacher. This change necessarily involves differences in how pupils are addressed, how work is organized, how expectations are made explicit or not, etc. In addition, as we have shown, differences between teachers (taken as individuals) are at least as numerous as differences between teachers of kindergarten and those of primary (taken collectively).

In addition, in terms of achievements, primary teachers' expectations of new pupils are either essentially behavioural (managing their own affairs, raising their hands, tidying away material, etc.) or having basic knowledge that facilitates school work (writing your first name, recognizing the letters of the alphabet, reciting the times-table, etc.). The change of teacher at primary level necessarily leads to a shift in the way expectations are expressed. This, added to the change in surroundings and fellow pupils, is likely to force pupils to deal with uncertainty and gives them the impression that they do not know the rules of the game.

Thus, if care is not taken to accompany this inevitable rupture, there is a risk that teachers of the first primary grades will believe their new pupils have not acquired the expected skills. This lack of recognition of skills acquired during kindergarten may make pupils regress in their learning. We consider it urgent to rethink the ways of handling the transition from kindergarten to primary school.

\section{Bibliography}

Amigues, R. \& Zerbato-Poudou M.-T. (2000). Comment l'enfant devient élève. Les apprentissages à l'école maternelle. Retz: Paris.

Bautier E. \& Goigoux R. (2004). Difficultés d'apprentissage, processus de secondarisation et pratiques enseignantes : une hypothèse relationnelle. Revue française de pédagogie, 148, 89-100.

Bautier, E. \& Rayou, P. (2013). La littératie scolaire: exigences et malentendus. Les registres de travail des élèves. Éducation et didactique, 7-2, 29-46.

Bodrova, E. (2008). Make-believe play versus academic skills: a Vygotskian approach to today's dilemma of early childhood education. European Early Childhood Education Research Journal, 16(3), 357-369.

Bodrova, E. \& Leong, D. (2011). Les outils de la pensée : L'approche vygotskienne dans l'éducation à la petite enfance. Québec: PUQ.

Cèbe, S. (2000). Développer la conceptualisation et la prise de conscience métacognitive à l'école maternelle : effets sur l'efficience scolaire ultérieure du CP au CÉ2. Une contribution à la prévention de l'échec scolaire des élèves de milieux populaires. Thèse de doctorat, non publiée, Université de Provence à Aix-en-Provence.

Charlesworth, R. (1998). Developmentally appropriate practice is for everyone. Childhood Education, 74(5), 274-282. Chervel, A. (1998). La culture scolaire. Une approche historique. Paris : Belin.

Chevallard, Y. (1991) La transposition didactique. Du savoir savant au savoir enseigné, Grenoble, La Pensée Sauvage (2e édition revue et augmentée, en coll. avec Marie-Alberte Joshua, 1re édition 1985).

Clerc-Georgy, A. (2017). Pas d'apprentissage sans imagination ni d'imagination sans apprentissage. In GFEN Maternelle, Apprendre à comprendre dès l'école maternelle. Réflexions, pratiques, outils. Lyon: Chronique Sociale. 
Hellenic Journal of Research in Education, Special Issue dedicated to the Scientific Symposium with International Participation: Lesson Study: A Scientific Meeting for Exchanging Views and Exploring the Model Across Europe, Alexandroupolis, 7 and 8 March 2017

Clerc-Georgy, A. (2016). L'imagination dans le développement de la créativité et de l'apprentissage. In I. Capron Puozzo (Dir.). La créativité en éducation et formation. Perspectives théoriques et pratiques (pp. 79-92). Bruxelles: De Boeck.

Clerc-Georgy, A. (2015). Le jeu à l'articulation entre apprentissage spontané et apprentissage réactif dans les premiers degrés de la scolarité. Actes du 6e séminaire pluridisciplinaire international Vygotski «Histoire, culture, développement : questions théoriques, recherches empiriques». Paris: CNAM.

Elias, C. L. \& Berk, L. E. (2002). Self-regulation in young children: Is there a role for sociodramatic play ? Early Childhood Research Quarterly, 17, 1-17.

Fernandez, M. L. (2005). Exploring "Lesson Study" in Teacher Preparation. Conference of the International Group for the Psychology of Mathematics Education, 305-312.

Gilliéron Giroud, P., Meyer, A. \& Veuthey, C. (2014). Pratiques déclarées d'enseignement et d'évaluation dans les premières années scolaires. Les spécificités de l'école enfantine en question. Renens: URSP, 158.

Laparra, M. \& Margolinas, C. (2016). Les premiers apprentissages scolaires à la loupe. Des liens entre énumération, oralité et littératie. Louvain-la-Neuve: De Boeck.

Nonnon E. (2004). Travail visible et invisible : la trace écrite au tableau. Traces, Recherches, 41, ARDPF, Lille, pp.17-31.

Martin, D. \& Clerc-Georgy, A. (2015). Use of theoretical concepts in Lesson Study: an example from teacher training. International Journal for Lesson and Learning Studies, 4(3), 261-273.

Pramling Samuelsson, I. \& Pramling, N. (2016). Variation Theory of Learning and Developmental Pedagogy: Two Context-related Models of Learning Grounded in Phenomenography. Scandinavian Journal of Educational Research, 60(3), 286-295.

Stigler, J. W. \& Hiebert, J. (1999). The Teaching Gap: Best Ideas from the World's Teachers for Improving Education in the Classroom. New York: The Free Press.

Takahashi, A. \& McDougal, T. (2016). Collaborative lesson research: maximizing the impact of lesson study. ZDM Mathematics Education, [online first]. Consulté le 17 février 2016, dans http://dx.doi.org/10.1007/s11858-015-0752-x

Vygotski, L.S. (1933/1967). Play and its role in the mental development of the child. Soviet Psychology, 5(3), 6-18.

Vygotski, L.S. (1935/1995). Apprentissage et développement à l'âge préscolaire. Société française, 2(52), 35-45. 